Nordic Journal of Religion and Society (2013), 26 (2): 121-139

\author{
Jonas Lindberg
}

\title{
RELIGION IN NORDIC PARTY PLATFORMS 1988-2008
}

\section{Abstract}

\begin{abstract}
In this article, I will analyse how Nordic political parties refer to religion in party platforms from the late 1980s until 2008 in light of increased religious diversity and changed relations between church and state in the Nordic countries. Four questions are asked: (1) Does the number of issueareas related to religion increase or decrease over time in the party platforms? (2) Does the connection between religion and other political issues, such as national identity, foreign policy, and human rights, change during this period? (3) How do the political parties view the positions of the majority churches and do they change over time? (4) What differences can be observed between the political parties in their approach to religion? The data consist of 136 party platforms from all the five Nordic countries in 1988, 1998, and 2008. The analysis shows that issues-areas related to religion increase in Denmark, Iceland, Finland and Sweden, but decrease slightly in Norway. Religion is often mentioned in connection to religious diversity and globalization. The position of the majority churches in party platforms is fairly strong over time, although to decreasing degree, particularly in Sweden and Norway. Finally, the traditional religious cleavage (Lipset and Rokkan 1967) is still evident in Nordic politics, although the rightwing populist parties complicates this picture as they tend to use religion to defend national values against consequences of religious diversity.
\end{abstract}

Keywords: religion, political parties, Nordic countries, Scandinavia, party platforms

\section{Introduction $^{1}$}

According to the dominant theories of secularization, the more modern a society becomes, the less religious it will be (Casanova 2011: 58). However, these theories have been increasingly criticized, nuanced and developed over the last decades (Berger 1992; Casanova 1994; Norris and Inglehart 2004) and in the trails of increasing globalization, religion has become visible in a different sense than before (Beyer 2007). As a consequence, religion has been claimed to re-emerge in politics with the increased transparency between national and international politics, in debates on the place of religion in decision-making and the quest for balance between mutual recognition of particularisms and freedom of expression (Foret and Itçaina 2012: 3). Among the most well known examples are the wearing of veils by Muslim women in public and/or in 
public positions such as among police officers in Western Europe and the violent reactions among some Muslim activists against the Danish Mohammad cartoons.

In the Nordic countries, the relationship between religion and politics has been studied by a number of scholars (e.g. Demerath 2000; Ahlbäck 2003; Madeley 2003; Demker 2005; Holberg 2007; Hagevi 2009; Knutsen 2010). During the time-period $1930-1980$, religion and particularly the state church system was initially contested by Communist and Social Democratic parties, but was later on more or less accepted (Gustafsson 1985). All the majority churches, whether state churches or not, have been assigned a special privilege and responsibility by the Nordic states, and they have continued to play a role in public life (Beckford 2010: 130). However, an increasing religious diversity is also a fact (Kühle 2011:208) and not the least an increased visibility of Islam, which poses challenges to formerly more or less mono-confessional countries (Casanova 2007: 66-67).

The aim of this article is to contribute to the current discussion on the role of religion in politics, by analysing changes in the way Nordic political parties refer to religion in their party platforms from around 1988, 1998 and 2008. Apart from a previous study on religious change in the Nordic countries 1930-1980 (Gustafsson 1985), no similar crossexamination has been conducted on religion in political party platforms in the Nordic countries. ${ }^{2}$ First, I will give a brief outline of Nordic politics and then give a further description of some aspects of religion and politics in the Nordic countries.

\section{Nordic politics}

The Nordic countries provide a very good case for comparative analysis (Przeworski and Teune 1970), as they have similar cultures and institutional arrangements (Esaiasson and Heidar 2000: ix). Part of their common characteristics is a universalistic welfare model that promotes similar rights and equality for all citizens (EspingAndersen 1990: 25; Ellingsæter and Leira 2006: 7).

According to a well-established model in the political sciences, four major cleavages have shaped Western European politics (Lipset and Rokkan 1967). The two first were shaped by the Reformation in the $16^{\text {th }}$ century and the Enlightenment in the $18^{\text {th }}$ century: centre/periphery (between urban elites and regional interests) and church/state (between religious and secular groups). The two latter were shaped by the Industrial Revolution in the $19^{\text {th }}$ century: owner/worker (economical class cleavage, between the political left-wing and right-wing) and urban/rural (industrial entrepreneurs promoting free markets versus land owners promoting protectionism).

In Nordic politics, a relatively stable five-party model developed along the cleavages: communist, social democratic, agrarian, liberal and conservative. For the most part of the $20^{\text {th }}$ century the Social Democratic/Labour parties dominated electorally, except in Iceland, where the liberal conservative Independence Party has been the major party (Arter 2008). During the course of the $20^{\text {th }}$ century, Christian Democrats also entered the parliaments in Norway (1933), Finland (1970), Denmark (1973) and Sweden (1985) (Arter 2008: 124). 
However, the relative stability changed towards the end of the century, due to increased levels of post-materialistic values among the Nordic populations, which affected voter preferences. Today, the Nordic countries are taking an outer position globally when it comes to the level of secular-rational and self-expression values (Inglehart and Welzel 2010: 554). This means that materialist, physical and economic values have decreased in importance. In politics, such post-materialistic values may explain the emergence of new political parties, such as new left and green parties, but also antiimmigration parties of the new right (Borre 2001: 90-91). The change has been labelled 'new politics' by several scholars although that concept has been questioned by others, as material values continue to play an important role in European politics (Borre 2001: 89-91). According to Ole Borre, the place of religious and moral issues is uncertain in the new politics scheme (2001: 91).

\section{Religion and politics in the Nordic countries}

In the Nordic countries, Denmark and Iceland still have established EvangelicalLutheran majority churches, while formal separations took place in Sweden in 2000, and in Norway in 2012. In the case of Finland, a separation took place already in 1919 between the state and the Evangelical Lutheran and the Finnish Orthodox churches, even if the state has retained close ties to the Evangelical-Lutheran Church (Kühle 2011: 205-207).

On the one hand, membership rates in the majority churches have remained relatively high: Denmark 79 percent, Finland (Evangelical Lutheran church) 76 percent, Iceland 80 percent, Norway 77 percent and Sweden 68 percent. $^{3}$ On the other hand, church attendance is low in international comparison: around four to five percent of the populations attend a church service at least once a week (Ingebritsen 2006: 26). The role of religion may then in general be labelled as 'cultural' (Demerath 2000: 127). In that sense, the majority churches may by some still be seen as forms of collective representation of nation states (Casanova 2001: 427).

Because of the more or less close ties between state and majority churches, the religious cleavage (Lipset and Rokkan 1967) has not become as contentious as in countries with a significant Catholic majority. In 1985, Ole Riis claimed that religion was a 'nonissue' in Danish politics, meaning that most parties discretely agreed on the importance of religious tolerance and the need for an open majority church (Riis 1985: 34). However, nonconformist religious groups, such as pietistic movements and Pentecostal churches, have actively contributed to the formation of Nordic liberal and Christian Democratic parties as reactions against higher levels of secular values in society (Arter 2008: 123-128; Madeley 2000: 34-35).

According to Gustafsson (1985), the focus of Nordic political debates on religion 1930-1980 centered on church organization and the relationship between the majority churches and the state. Gustafsson argues that the general development was that of secularization. The religious cleavage was identified as a divider between left-wing and centre-right parties. The Social Democrats in Denmark changed over time from a very 
critical standpoint into viewing the majority church as part of the local welfare system (Riis 1985: 26). In Sweden, a similar development took place and there was as a growing understanding of common values between the politically dominant Social Democratic party and the majority church (Ahlbäck 2003: 172; Fridolfsson et al. 2009: 177). In Finland (Sundback 1985: 71), Iceland (Pétursson 1985: 114) and Norway (Lundby 1985: 157-158) the patterns were similar.

In the Nordic countries, religion has for long played an important part for voter preference and the reason may be that religion was part of the basic cleavages in the formation of western European politics (Lipset and Rokkan 1967) and that it still reflects values, which influence voting behaviour (Knutsen 2010: 1). More recent Norwegian and Swedish surveys show that voters for the centre-right in general are somewhat more positive towards religion than those on the left-wing side (Aardal 2007: 5354; Hagevi 2010: 135-144). However, religious voters are not easily placed on either side of the traditional left/right scale, as that scale primarily is based on the economic class cleavage (Demker 1998: 169). Survey data from Sweden shows that religious voters tend to hold traditionally authoritarian political right-wing values on ethical issues and traditionally libertarian political left values on immigration issues, as an example (Hagevi 2011: 266-267).

Today, the Nordic countries are characterized by a growing religious diversity, in part due to immigration. In Norway, almost 600 religious organizations have gained legal recognition and are thus financially eligible by the state, and the picture is similar in the other Nordic countries (Kühle 2011:208). About three percent of the populations in Denmark and Sweden have been estimated to be Muslims, while only about 0.4 percent in Finland (Buijs and Rath 2006). In terms of immigration, about 13 percent of the Swedish population were born abroad, about ten percent in Iceland, about eight percent in Denmark and Norway and about four percent in Finland (Norden 2013).

In the trails of globalization, diversity and pluralism grows, and a new form of critique towards certain religions, sometimes expressed in xenophobic ways, has started to emerge in the Nordic countries. Survey data shows that right-wing populist parties increasingly tend to attract voters in Denmark and Norway with a low religious commitment, as opposed to Christian Democratic voters, with a high religious commitment and no correlation between religiosity and xenophobia (Aardal 2007: 74-75; Knutsen 2010: 15). In response to the changed Nordic political landscape, John Madeley (2000: 41) has suggested that a more contemporary version of the religious cleavage should be tripolar in the sense that Christian Democrats take a centrist position, between the new left of the left-socialists and the new right of the neo-liberal progress parties, all driven by the increased focus on post-materialist values.

To conclude, the religious cleavage (Lipset and Rokkan 1967) has been less contentious in the Nordic countries than in many other countries, due to the close relationship between the majority churches and the states. However, with the growth of secular-rational values (Inglehart and Welzel 2010: 554) and increasing religious diversity (Kühle 2011: 208) the picture is changing. In this article, I will examine how these changes affect the way political parties refer to religion through an empirical 
study of party platforms. Therefore I will give an overview of party platforms, before I further discuss the methodology.

\section{The role of party platforms}

Party platforms constitute a core source of information about policy positions of political actors (Aardal et al. 2004: 386-387). These strategic statements on long-term ideological positions are developed by the members of each organization and decided by a democratic vote, usually by the party congress. This process might be called a 'political liturgy', a ritual for the party, where the plea of allegiance to common core values is an important part (Høigård 1978: 14; Anderson and Furberg 1973: 84). The purpose is to provide both voters and the political system in general with an overview of the values and current policy intentions of the party, as well as being identity markers for members and affiliates. Consequently, party platforms can be used as sources of data of the changes of party policy positions over time (Høigård 1978: 11-15; Narud and Valen 2004: 33-34; Skjeie 1992: 44; Laver and Garry 2000: 620). The platforms must not, however, be mistaken for realpolitik as in the case of election manifestos, but are rather expressions of a perceived identity.

As the aim of this study is to analyse changes in the views of such a core value as religion among the Nordic political parties over time, party platforms provide good sources of information. A number of studies on such documents have been made during the last decades in the Nordic countries (e.g. Green-Pedersen 2005; Sorensen 2011; Kestilä 2006; Thorhallsson and Rebhan 2011; Aardal et al. 2004; Holberg 2007). In this study, I have used party platforms to analyse policy statements on different issues, including religion. For example Sorensen (2011), found that religion affects social policy development in Sweden and Norway. With the exception of this study, few analyse party platforms across country boundaries. This analysis will contribute to that body of research in its comparative perspective across the Nordic countries and with its focus on religion.

It should be noted that party platforms come in different forms. In some cases, they may be as brief as one page, but they are more commonly $20-50$ pages. They may be called party platforms, but other labels do also occur. Work platforms are similar to election manifestos, but should not primarily be seen as election propaganda and principle platforms are more long-term than an election term (Høigård 1978: 10-21). At least to some parties the different labels do not have any effect in practice on the content and function of the platform (Tvedten 2010: 3). In this study different kinds of party platforms will be used and treated equally, but carefully with regards to possible differences in character. In two cases (True Finns 2006/07 and Radical Left 2011), election manifestos have been used, due to a lack of any party platform from around 2008. These somewhat different characters might be considered a weakness of the reliability of the study. However, with these weaknesses in mind, the extent of the study, both geographically and over time should still provide us with a unique overview of the different ways in which Nordic political parties address the issue of religion. 


\section{Methodology}

The aim of this study is to analyse the possible changes in the way Nordic political parties refer to religion in their party platforms from around 1988, 1998 and 2008.

I ask four questions: 1. Does the number of issue-areas (an empirically generated group of issues that share one ore more traits) related to religion increase or decrease over time in Nordic party platforms? This is a quantitative way to determine whether religion is more frequently addressed in general in party platforms, regardless of the volume of each platform.

2. Does the connection between religion and other political issues, such as national identity, foreign policy, and human rights, change during this period? This is a quantitative way to determine if the references to religion enter new areas and/or leave others, with the intention to find out how the content of party platforms reflects changes in society. Possible examples may be a move from traditional religious issue-areas such as organized religion and national identity to issue-areas such as foreign policy, human rights and/or immigration.

3. How do the political parties view the positions of the majority churches and do they change over time? This is a qualitative way of determining a possibly changing view of the majority church in each country.

4. What differences can be observed between the political parties in their approach to religion? This is a quantitative and qualitative way to determine how visible the religious cleavage is today (Lipset and Rokkan 1967). The expected result, in accordance with Lipset and Rokkan's theory, is a somewhat higher number of issue-areas in platforms from political parties on the traditional right-wing, than from the parties on the left-wing. The highest number of issue-areas would be expected in platforms from the Christian Democratic parties. Any deviations from the expected results will indicate a change in how the religious cleavage ought to be interpreted today and how the higher degree of secular-rational values (Inglehart and Welzel 2010: 554) and increasing religious diversity (Kühle 2011: 208) may have affected this.

Before we turn to the analysis of the empirical data, two key concepts need to be defined. The first one is religion, which I use in a traditional substantial sense as beliefs, language, symbols, activities and institutions that are being used to regulate the cleavage between the empirical and super-empirical perceptions of reality (Hill 1973: 42-43). The second key concept is politics, which here is considered to be decision making regarding the distribution of values, such as material ones - economic, natural resources etc. - and non-material - for example norms on what is beneficial and destructive for society (Easton 1965: 50). The related concept of a political party was defined by Anthony Downs (1957) as «a team of men [sic!] seeking control over the governing apparatus by gaining office in a duly constituted election» (1957: 25).

The unit of analysis of the empirical study here consists of 136 party platforms or, in three cases (Swedish Centre Party 2009, Swedish Christian Democrats 2010-11 and Radical Left 2011) collections of documents from 44 political parties. ${ }^{4}$ Of these are 109 digitally searchable and the rest have been examined manually. ${ }^{5}$ Each of the chosen platforms was published in the years close to 1988,1998 and 2008. The choice 
of years has been inspired by a similar study on religious change from 1938 to 1958 and 1978 in the Nordic countries (Gustafsson 1985). The documents include party platforms from the Sweden Democrats, in spite of the fact that the party did not get elected to the Swedish parliament until 2010. The reason for including these platforms is that it makes it possible to compare right-wing populist parties in all of the Nordic countries, except Iceland, which has no such party.

The party platforms have been studied through the use of content analysis (Krippendorff 1980; Graneheim and Lundman 2004) in three steps: a) Keywords (Graneheim and Lundman 2004: 106): a set of 36 keywords was used to find sentences related to religion in each party platform. ${ }^{6}$ b) Quasi-sentences (Manifesto Project 2013): each sentence with one or more of the keywords was analysed and from these, quasi-sentences, meaning arguments expressing a political idea or issue, were extracted. ${ }^{7} \mathrm{c}$ ) Issue-areas (Brewer 1992: 300): the visible content (Krippendorff 1980; Graneheim and Lundman 2004: 106) of the quasi-sentences was finally categorized into 18 empirically generated issue-areas, meaning a group of issues that share one or more traits, such as foreign policy issues or social policy issues. ${ }^{8}$ The analysis is based on the issueareas, whereas the keywords and quasi-sentences only have functioned as a way of obtaining these.

\section{Empirical comparative analysis}

In the following, I intend to answer each of these questions country by country and add clarifying examples and quotes. The countries are placed on a continuum, with Denmark at one end, demonstrating a higher degree of change in issue-areas related to religion and tensions around these. At the other end is Iceland, which demonstrates a lower degree of these indicators.

\section{Denmark}

With regards to the first question about the number of issue-areas related to religion, only seven political parties had seats in the Danish parliament 1988-2008. Therefore I will only include them, when I first examine the quantitative change over time, and exclude the Centre Democrats, Liberal Alliance, the Progress Party and the Danish People's Party. However, later in the analysis these parties will be included as well. During 1988-2008, the total number of issue-areas concerning religion increased in the party platforms from 20 to 29 .

Secondly, about what kind of issue-areas that are being related to religion, the most obvious changes from 1988 to 2008 are that the human rights issue-area increases from two to all seven platforms, the immigration issue-area increases from zero to four platforms and the foreign policy issue-area increases from two to four platforms. Of the other issue-areas, the most common are party identity (down from 3 in 1988 to 2 in 2008), national identity (up from 3 in 1988 to 4 in 2008) and organized religion (steady at 4). The major change over time can be described as increased tensions between what is perceived as Danish values (Christianity and/or human rights, including democracy), 
in relation to foreign policy and immigration. To many parties it is an act of balance, as in this example from the Liberals: «With respect for the fundamental values of the Danish society it is a necessary prerequisite for the schools to tailor teaching to different cultural, religious or political beliefs to be inclusive» (The Liberals 2006).

Third, in asking about the position of the majority church, only the Socialist People's Party and the Progress Party question the relationship between the state and the majority church, although Liberal Alliance states that this church should not interfere with state policies and vice versa. Red-Green Alliance and Social Liberals criticize the majority church for its negative attitude towards gay rights, but apart from these examples the church receives full support whenever it is mentioned in a platform.

Fourth, regarding the political parties and their approach to religion, the parties on the traditional left-wing (Red-Green Alliance, Socialist People's Party and Social Democrats) refer less to issue-areas related to religion (20 issue-areas in total 19882008) than parties on the traditional right-wing (Social Liberals, Liberals and Conservative) (28 issue-areas in total 1988-2008. The left-wing parties refer slightly more to human rights (in a total of 7 platforms 1988-2008 compared to 6 platforms for the right-wing parties). The right-wing parties refer more to organized religion (in a total of 6 platforms 1988-2008 compared to 4 platforms for the left-wing parties), Christianity as part of party identity (in a total of 3 platforms 1988-2008 compared to 0 for the left-wing parties) and Christianity as part of national identity (in a total of 6 platforms 1988-2008 compared to 1 for the left-wing parties). The Christian Democrats is the party that refer most often to issue-areas related to religion (26 times in total in three platforms 1988-2008). However, the Danish People's Party refer to as much as 20 issue-areas related to religion in just two platforms (1998-2008). That is substantially more than its political predecessor the Progress party did in two platforms (6 times in total 1988-1998). Unlike the Christian Democrats, the Danish People's Party does not refer to Christianity (or any religion) in relation to party identity and environmental issues, but instead in relation to equality, crime and food and animal care. Finally, the Danish People's Party is very critical about 'non-Danish' religion, as in this example:

To the Danish People's Party, it is important to point out that religion, faith, values, traditions, customs and attitudes are crucial for any community development. It is only the Judeo-Christian, Western cultural sphere that has managed to do away with the medieval worldview (The Danish People's Party 2009).

To conclude, the total number of issue-areas has increased in Danish party platforms 1988-2008 from 20 to 29 , which is most visible in the immigration and human rights issue-areas. The majority church is well supported in the party platforms. Parties on the political right-wing refer to religion more often than parties on the left-wing and Christian Democrats do so to the highest degree, closely followed by the Danish People's Party. 


\section{Norway}

In regards to the first question, all seven Norwegian parliamentary parties are included in this study and their platforms contain the highest total number of issue-areas related to religion in the Nordic countries. However, the Norwegian case is also the only one where the total number of issue-areas has decreased somewhat over time from 43 in 1988 to 39 in 2008, with 51 in the platforms from around 1998.

Secondly, about the connection between religion and other political issues, a decrease is notable in education (from a total of 6 platforms in 1988 to 3 in 2008) and health care and other welfare (from a total of 3 platforms in 1988 to 1 in 2008). A temporary increase was visible in the platforms from around 1998 in the issue-areas immigration (from a total of 3 in 1988 to 6 in 1998), foreign policy (from a total of 3 in 1988 to 7 in 1998) and security (from a total of 1 in 1988 to 4 in 1998). The only increase for the whole timeframe is in culture (from a total of 1 in 1988 to 3 in 2008). The most common issue-areas are party identity (all parties except the Labour Party in at least one and in most cases all of their platforms), national identity (all parties except the Socialist Left Party in at least one of their platforms), human rights (all parties in all of their platforms) and organized religion (all parties in all of their platforms). The multireligious society gets support from most parties but religion is also in some cases claimed to be part of the tensions that arise in relation to international conflicts and immigration (Socialist Left Party, Labour Party, Centre Party, Christian Democrats and Progress Party). Three parties point to the need for non-native religious leaders to learn about Norwegian values to be allowed to practice in Norway (Labour Party, Centre Party and Christian Democrats). In a similar way, religion is in some cases portrayed as a threat to other human rights (Socialist Left Party, Labour Party and Progress Party), as in this example from the Labour Party: «In many parts of the world, violations of human rights particularly affect women. Norway should work against discrimination against women in all areas. Religion can be no excuse for violating human rights» (Labour Party 1997).

Third, about the position of the majority church, a majority of the parties have changed their views on church and state relations 1988-2008, to become more positive towards a separation of the two. The argument holds that the majority church is best served by being independent when it comes to decision-making.

Fourth, regarding the political parties and their approach to religion, the parties on the traditional left-wing (Socialist Left Party and Labour Party) refer to issue-areas related to religion at about the same extent (an average of about 18 in each party) as parties on the traditional right-wing (Liberal Party, Conservative Party and here including the Centre Party as well, although it has formed coalitions with left-wing parties). However, the Labour Party in particular pay more attention to religion in relation to welfare and both left-wing parties refer to religion in relation to equality in all of the three platforms, whereas such references are totally absent from the platforms of the right-wing parties. Right-wing parties refer to religion in relation to party identity, national identity and culture to a higher degree. The Christian Democratic Party refers most often to issue-areas related to religion (36 times over three platforms), including (ethical issues in) scientific research and environmental policy, which no other party 
does. The Progress Party is similar to the Conservative Party in the total number of issue-areas that they cover (19 in both cases) as well as which ones to a high degree. However, the Progress Party in some cases holds a more critical stance to religion other than Christianity in relation to immigration, security, healthcare and crime.

To conclude, Norwegian party platforms contain the highest number of issue-areas related to religion 1988-2008 compared to the other Nordic countries, but with a decrease from 43 in 1988 to 39 in 2008. However, an increase was visible from 1988 to 1998 in the immigration, foreign policy and security issue-areas. The view of majority church and state has changed from 1988 to 2008 to become more positive towards a separation. Left-wing and right-wing parties refer to religion to about the same extent, but with more focus on welfare and human rights, whereas right-wing parties refer more to party identity, national identity and culture.

\section{Sweden}

To answer the first question about the number of issue-areas related to religion, party platforms from the seven parliamentary parties 1988-2008 have been included as well as platforms from the Sweden Democrats to enable comparisons with other right-wing populist parties. The short-lived New Democracy had no references to religion at all in its brief platform from 1991. The total number of issue-areas increased slightly from 28 to 32 from 1988 to 2008 .

Secondly, in regards to the connection between religion and other political issues, religion has become less common in relation to party identity (from a total of 5 platforms in 1988 to 2 in 2008) and more common in relation to human rights (from a total of 6 platforms in 1988 to 8 in 2008). The most common issue-areas are organized religion (3-5 platforms each of the years) and human rights. Overall, the change can be described as a higher focus on religion in general, rather than Christianity and the majority church, as fewer parties refer to Christianity as part of national and/or party identity over time. Human rights are almost as much emphasized here as in the Norwegian party platforms. Critical stances towards religion are associated with perceptions of religion as a threat to human rights (as expressed by the Green Party, Social Democrats and Liberal People's Party), in association with international conflicts (Christian Democrats) and in relation to immigration and Islam (Sweden Democrats). Here is an example from the party platform of the Social Democrats:

Culture and religion contribute to people's identity and enrichen community life. Cultural and religious diversity must be welcomed to the extent it does not impose restrictions on other people's rights and opportunities to make their own choices in life (The Social Democrats 2001).

Thirdly, about the position of the majority church, the separation between church and state took place in 2000, but five out of seven parties call for an even further separation in their platforms from 2008, as the majority church still holds a privileged position in law and the Constitution (Left Party, Green Party, Centre Party, Liberal People's Party, Christian Democrats). What may be noted is the total lack of references to the majority church in the extensive Social Democratic platforms. 
In the fourth question we ask about the position of the political parties in relation to religion and the parties on the traditional left-wing (Left Party, Green Party and Social Democrats) refer to issue-areas related to religion less often (22 compared to 34 issueareas in total 1988-2008) than parties on the traditional right-wing (Moderate Party, Liberal People's Party and Centre Party). The left-wing parties refer to religion as part of human rights in all of their platforms, but just in single cases in relation to other issue-areas. The Social Democrats refer in two of their platforms to having a common ancestry with the religious revival movements in the $19^{\text {th }}$ century as part of their party identity. The Christian Democrats refers most often to issue-areas related to religion (26 times in three platforms) and focus stronger than other parties on Christianity as part of party identity, education, culture, environmental policy, health care and other welfare. The Sweden Democrats refer to religion in similar issue-areas as the Moderate Party, although not in relation to party identity. Other differences are their focus on religion in relation to security and critical stances towards religion other than Christianity in relation to equality and food and animal care.

To conclude, the total number issue-areas related to religion in Swedish party platforms increase from 28 in 1988 to 32 in 2008, with an increasing focus on religion in general and a decreasing focus on Christianity. Most parties call for a further separation of majority church and state, for the sake of equal treatment of all religious bodies. Left-wing parties refer less often to religion and to a higher degree in relation to human rights and right-wing parties refer more to religion in comparison with more focus on Christianity.

\section{Finland}

First, if we count the True Finns and its predecessor the Finnish Rural Party as one party here, all of the eight parties in this study existed during the whole timeframe. In their party platforms, the total number of issue-areas related to religion that has been addressed increase from 22 to 29 .

Second, there are few differences over time, in regards to which issue-areas are being addressed. Slight increases are notable in culture (from a total of 1 in 1988 to 3 in 2008), immigration (from a total of 0 in 1988 to 2 in 2008) and security (from a total of 1 in 1988 to 3 in 2008). When religion is associated with international conflicts it is in an increasingly problematizing way (in those cases by the Green League, Christian Democrats and True Finns). The most common issue-areas are (Christianity as part of) national identity (4-5 platforms each year), human rights (4-5 platforms each year) and organized religion (3-4 platforms each year).

Third, the party platforms contain few explicit references to the majority churches, but when they do it is in relation to international aid, cultural heritage, celebrating church services in Swedish (Swedish People's Party) and as important agents in civil society. The only possible criticism of the state's relationship to the EvangelicalLutheran majority church is when the Left Alliance states that the authority of the state should not rely on religion. Six out of eight parties refer to Christianity as a source of 
national core values at least in one of its platforms, such as in this case, the Centre Party:

The Christian tradition has shaped our culture over the centuries and is still an important basis for our society. Churches and other religious communities create opportunities for activities, which promote the human capacity to behave ethically (The Centre Party 2006).

Fourth, the parties on the traditional left-wing (Left Alliance, Social Democrats and Green League) refer less to issue-areas related to religion (a total of 16 issue-areas 1988-2008) than parties on the traditional right-wing (Swedish People's Party, National Coalition Party and here including the Centre Party as well, although it has formed coalitions with left-wing parties) (a total of 29 issue-areas 1988-2008). The left-wing parties (in this case Green League) only refer to immigration (a total of 2 platforms 1988-2008) more than the right-wing parties (a total of 1 platform 1988-2008). The right-wing parties refer more to most other issue-areas more often, most notably to (Christianity as part of) national identity (a total of 8 platforms 1988-2008 compared to 1 for the left-wing parties) and organized religion (a total of 6 platforms 1988-2008 compared to 2 for the left-wing parties). The Christian Democrats is the party that refer most often to issue-areas related to religion ( 28 times in three platforms). The True Finns/Finnish Rural Party refer to religion less often than other right-wing parties, but slightly increasingly so (from 1 issue-area in 1988 to 3 in 2008), focusing more on religion in relation to foreign policies, security and health care.

To conclude, the total number issue-areas related to religion in Finnish party platforms increase from 22 in 1988 to 29 in 2008, with a slightly increased focus on security and culture issue-areas. The platforms contain few references to the majority church, but state to a high degree the importance of Christianity for society. The leftwing parties refer less to religion than right-wing parties and focus slightly more on immigration and the right-wing parties focus more on Christianity.

\section{Iceland}

First, only three parties (Independence Party, Progressive Party and Social Democratic Alliance, which could be argued to be a direct continuation of the Social Democratic Party) have existed during the whole timeframe here, which gives us few platforms to compare over time. However, it may still be noted that among these parties the total number of issue-areas increases in the party platforms from 13 in 1988 to 18 in 2008. The change is most visible in the platforms of the Progressive party (from a total of 7 in 1988 to 12 in 2008), but also in the platforms of two parties that appeared later - the Left Green (from a total of 0 in 1998 to 7 in 2008) and Liberal parties (from a total of 3 in 1998 to 5 in 2008).

Second, among the three parties that have been active for the whole timeframe (Independence Party, Progressive Party and Social Democratic parties), a slight increase is notable in immigration, security, trade and industry and equality (from a total of 1 in 1988 to 2 in 2008). In the two platforms of the Left Green and Liberal par- 
ties, a similar increase (from a total of 0 in 1988 to 2 in 2008) is visible in the equality and education issue-areas.

Third, four of five parties in the parliament from 1998-2008 refer to the majority church in at least one platform, but only the Liberal Party explicitly calls for a separation of church and state. It should also be noted that the major Independence Party has moved from a strong focus on Christianity and majority church in 1988 towards a strong focus on religion in general in a number of issue-areas, including party and national identity in 2008. Thereby it has joined the majority of the other parties.

Fourth, most of the parties on the traditional left-wing (Association for Equality and Sociality, People's Alliance, Women's List, Social Democratic Party/Alliance and Left Green) make no or very few references to religion. The Social Democrats refer to religion in relation to the issue-areas of health care and human rights. However, the Left Green Party is a major exception in that it in its 2007 platform makes references to religion in seven issue-areas, as compared to five for the Liberal Party. The parties on the traditional right-wing (Independence Party, Progressive Party, Liberal Party and Citizen's Party) most commonly refer to religion in issue-areas such as party identity (all 4 parties at least in one platform) and national identity (3 parties in at least one platform). Iceland has never had neither a Christian Democratic nor a right-wing populist party.

To conclude, the total number issue-areas related to religion in Icelandic party platforms increase from 13 in 1988 to 18 in 2008, with slight increases in the immigration, security, trade and industry and equality issue-areas. The majority church is assigned a fairly strong position in the party platforms over time, although the general tendency is decreasing focus on Christianity. The majority of the left-wing parties make no or few references to religion in their platforms, with the exception of the Green Party in 2008. Right-wing parties refer to religion more often, and particularly in relation to party and national identity.

\section{Conclusions and discussion}

The aim of this study has been to contribute to the current discussion on the role of religion in politics, by analysing possible changes in the way Nordic political parties refer to religion in their party platforms from around 1988, 1998 and 2008. In order to pursue this aim, four questions have been asked. First, the data will be presented and then discussed in relation to earlier research.

1. Does the number of issue-areas related to religion increase or decrease over time in Nordic party platforms? The data show that the number of issue-areas has increased most of all in Denmark followed in turn by Iceland, Finland and Sweden. In Norway, an increase took place between 1988 and 1998, but by 2008 the result was a slight decrease in total. However, the total number of addressed issue-areas is continuously the highest in Norway.

2. Does the connection between religion and other political issues, such as national identity, foreign policy, and human rights, change during this period? I find that reli- 
gion occurs to a higher degree over time in issue-areas such as human rights, immigration, security and foreign policy and that all of these issue-areas may be associated with tensions. If we place the countries on a continuum from a higher to a lower degree of this change then we get the following order: Denmark, Norway, Sweden, Finland and Iceland.

3. How do the political parties view the positions of the majority churches and do they change over time? The majority churches receive a high degree of support in Denmark and Iceland and a lesser degree in Finland, albeit in a positive way. In Norway, the statements in the party platforms generally change from supporting the state church system in 1988 to supporting a separation of the state and the majority church in 2008, although framed as being for the benefit of the church. In Sweden, a majority of the parties in 2008 would like to see an even further separation of church and state, for the sake of equal treatment of all religious bodies.

4. What differences can be observed between the political parties in their approach to religion? I find that in all the countries, the parties on the traditional left-wing refer to fewer issue-areas in relation to religion than parties on the traditional right-wing and focus more on human rights and welfare. Parties on the right-wing focus more on Christianity as part of national and party identity and organized religion (primarily the majority church). The Christian Democratic parties refer most frequently to different issue-areas related to religion and focus as well on some areas that other parties do not, such as religion in relation to environmental policy. The right-wing populist parties are similar to either Christian Democratic or Conservative parties in the number of issueareas that they touch upon, but differ from these in their lack of references to Christianity in relation to party identity and in having a more critical stance towards other religions than Christianity. Next, I will analyse these results in relation to previous research.

The first finding in this study, that the total number of issue-areas related to religion in party platforms has increased, may be interpreted in line with claims of a re-emergence of religion in politics (Foret and Itçaina 2012), but not by itself. However, the increase is in general related to issue-areas such as human rights, immigration, security and foreign policy, which I interpret as signs of a higher degree of religious diversity (Kühle 2011: 208) and effects of globalization (Beyer 2007). Together, these findings may strengthen claims of a re-emergence in politics in the Nordic countries, due to such social change.

In the second finding, the increased religious diversity is interesting to compare with the position of the majority churches in the party platforms. In Norway and Sweden, the support of the state church system generally has turned into a call for disestablishment and such a separation has now taken place in both countries. In Finland, the state retains a close relationship between the majority church and the state, in spite of formal separation (Kühle 2011: 205-207). In Denmark and Iceland, few such statements are being made in the party platforms and these countries retain their state church systems. However, in relation to the way religious diversity is expressed in party platforms we get an interesting finding. On a continuum, Denmark has been placed here on one end, with a higher degree of change in issue-areas related to religion 
and more tensions and focus on human rights, immigration, security and foreign policy. Iceland has been placed on the other end, with a lower degree of similar indicators. It may be noted that this continuum does not follow the levels of immigration in the Nordic countries, with the highest levels in Sweden and the lowest in Finland (Norden 2013). The conclusion may be that the position of the majority church in party platforms is not necessarily affected by the way religious diversity is accounted for.

The third finding in this study is that the theory of a religious cleavage (Lipset and Rokkan 1967) is still applicable on Nordic politics. As expected, left-wing parties in general refer to religion less often than right-wing parties, and to a higher degree focus on human rights and welfare, whereas right-wing parties focus more on party and national identity, and organized religion. The fact that Christian Democrats refer most often to religion is not a surprise either, in relation to Lipset and Rokkan's theory. However, as right-wing populist parties have entered Nordic politics a new approach to religion is visible, in their focus on religion as part of a discourse on cultural identity as opposed to what they perceive to be foreign values.

Therefore, the fourth finding in this study is that the religious cleavage also has become more complex than before. Now the cleavage is not necessarily just an expression of the conflict between secular and religious values, but also between different religions, primarily between Christianity and Islam in the sense that Christianity represents the core values in Nordic societies. John Madeley's (2000: 41) suggestion of a tripolar religious cleavage may be applicable here, as the parties of the new right, primarily represented by the right-wing populists, engaged in a discourse on values and religion, but from a different angle than the Christian Democrats. If the place of religious and moral issues in the new politics scheme was uncertain to Ole Borre (2001: 91), this article has contributed to a wider understanding of that.

To conclude, this study of Nordic party platforms 1988-2008 shows an increased religious diversity, which makes religion a factor in new issue-areas such as human rights, immigration, security and foreign policy. The position of the majority churches in party platforms is fairly strong over time, although to decreasing degree, particularly in Sweden and Norway. Finally, the religious cleavage is still an applicable theory in Nordic politics, although the emergence of right-wing populist parties show a more complex side of it, where religion is used to defend national values against consequences of religious diversity.

\section{Notes}

1 With special thanks to professor Mia Lövheim, professor Inger Furseth, assistant professor Magnus Hagevi and professor Grace Davie for valuable comments.

2 This study is part of the NOREL program 2010-14, which in part is a follow-up of the Gustafsson study, and aims to study religious change in the Nordic countries 1988-2008. NOREL is a NORDCORP project (Nordic Collaborative Research Project) awarded by Joint Committee for Nordic Research Councils for the Humanities and the Social sciences (NOS-HS) and is conducted by professor Inger Furseth. For further information, please visit www.religioninpublicsphere.no. 
3 The membership figures have been collected from the webpage of each church (years within parenthesis): Church of Denmark (2013), Church of Iceland (2013), Church of Norway (2012), Church of Sweden (2013) and Evangelical-Lutheran Church of Finland (2012).

4 A total of 44 political parties have had seats in the Nordic parliaments during 1988-2008, with the addition of the Sweden Democrats, to enable comparisons between the right-wing populist parties.

5 The Icelandic material has been examined and in a number of cases translated by Bjarni Randver Sigurvinsson, University of Iceland, and Katriina Järvenpää, Church Research Institute in Finland, has been helpful with some of the Finnish documents. All other translations have been made by Jonas Lindberg.

6 Keywords: *religi*, Islam, Christianity, Judaism, Hinduism, Buddhism, church, mosque, synagogue, temple, Jesus, God, Prophet, Buddha, bishop, minister, pastor, imam (or similar in other religions), deacon*, congregation, worship, Bible, Quran, Satanism, angels, meditation, spiritual (ten findings were removed, as they were considered irrelevant, due do a wider use of the word in the Nordic languages than in English), new age, hijab, cross (and similar religious symbols), faith, holy, secular, secularization, life stance and atheism.

7 As a sentence may contain more than one argument, these were divided by the use of punctuation, thus turning the arguments into quasi-sentences (Budge et al. 2001: 96; Laver and Garry 2000: 624). An example could be the division of the sentence «the freedom of religion is very important, but the majority church holds a unique position» into two quasi-sentences, in this case one on each side of the comma sign.

8 Issue-areas: Party identity (expressing the origin and core values of a party, usually in the portal paragraph), national identity (if national core values are connected to religion), rights (the freedom of religion), education (on all levels), culture (arts, music etc.), immigration, foreign policies (including foreign aid, but not armed conflicts), security (in relation to existing or potential conflicts), trade and industry, healthcare (medical issues related to religion), scientific research (mainly ethical issues), environmental policy (mainly ethical perspectives), organized religion (primarily the majority churches, but in some cases also other denominations and religious bodies), welfare (other than healthcare), food and animal care (e g ritual slaughter), labour market (in cases where religious affiliation affects work conditions), equality (gender and sexuality) and crime (including correctional care).

\section{References}

Aardal, Bernt Olav, Anne Krogstad and Hanne Marthe Narud 2004. Valgkamp på norsk (Election Campaign in Norwegian). In I valgkampens hete. Strategisk kommunikasjon og politisk usikkerhet, Bernt Olav Aardal, Anne Krogstad and Hanne Marthe Narud (eds.), 383-398. Oslo: Universitetsforlaget.

Aardal, Bernt (ed.) 2007. Norske velgere: en studie av stortingsvalget 2005 (Norwegian Voters: a Study of the Storting Election 2005). Oslo: Damm.

Ahlbäck, Lennart 2003. Socialdemokratisk kyrkosyn. En studie i Socialdemokraternas kyrkopolitiska riktlinjer 1979-1996 (Social Democratic Ecclesiology. A Study of Social Democratic Church Polices 1979-1996). Lund: Arcus.

Anderson, Jan and Mats Furberg 1973. Politik och propaganda: Om röstvärvandets semantik (Politics and Propaganda. About the Semantics in Voter Appeal). Stockholm: Aldus.

Arter, David 2008. Scandinavian Politics Today. 2 ed. Manchester: Manchester University Press. 
Beckford, James A. 2010. The Return of Public Religion? A Critical Assessment of a Popular Claim. Nordic Journal of Religion and Society. 23(2): 121-136.

Berger, Peter 1992. A Far Glory: The Quest for Faith in an Age of Credulity. New York: Free Press.

Beyer, Peter. 2007. «Globalization and Glocalization». In The Sage handbook of the sociology of religion, James A Beckford and Nicholas J. Demerath (eds.), 98-117. Los Angeles: Sage Publications.

Borre, Ole 2001. Issue Voting: an Introduction. Aarhus: Aarhus University Press.

Brewer, Thomas L. 1992. An Issue-Area Approach to the Analysis of MNE-Government Relations. Journal of International Business Studies. 23(2): 295-309.

Budge, Ian, Hans-Dieter Klingemann, Andrea Volkens, Judith Bara and Eric Tanenbaum 2001. Mapping Policy Preferences. Estimates for Parties, Electors, and Governments 1945-1998. Oxford: Oxford University Press.

Buijs, Frank J. and Jan Rath 2006. Muslims in Europe: The State of Research. IMISCOE Working Paper. Available from: http://dare.uva.nl/document/144737 [Accessed 13 August 2013].

Casanova, José 1994. Public Religions in the Modern World. Chicago: University of Chicago Press.

Casanova, José 2001. 2000 Presidential Address. Religion, the New Millennium, and Globalization. Sociology of Religion, 62(4): 415-441.

Casanova, José 2007. Immigration and the New Religious Pluralism. A European Union/United States Comparison. In Democracy and the New Religious Pluralism, Thomas F. Banchoff (ed.), 59-84. New York: Oxford University Press.

Casanova, José 2011. The Secular, Secularizations, Secularisms. In Rethinking Secularism, Craig Calhoun, Mark Juergensmeyer and Jonathan VanAntwerpen (eds.), 54-74. New York: Oxford University Press.

Church of Denmark 2013 [online]. Available from: www.folkekirken.dk [Accessed 13 September 2013].

Church of Iceland 2013 [online]. Available from: www.kirkjan.is [Accessed 13 September 2013].

Church of Norway 2012 [online]. Available from: www.kirken.no [Accessed 13 September 2013].

Church of Sweden 2013 [online]. Available from: www.svenskakyrkan.se [Accessed 13 September 2013].

Demerath, Nicholas Jay 2000. The Rise of 'Cultural Religion' in European Christianity: Learning from Poland, Northern Ireland, and Sweden. Social Compass 47(1): 127-139.

Demker, Marie 1998. Religion och politik (Religion and Politics). Stockholm: SNS Förlag.

Demker, Marie 2005. Europas kristdemokrati - partier och ideologi (European Christian Democracy - Parties and Ideologies). In Religion och politik, Magnus Hagevi (ed.), 116-133. Malmö: Liber.

Downs, Anthony 1957. An Economic Theory of Democracy. New York: Harper \& Row.

Easton, David 1965. A Framework for Political Analysis. Englewood Cliffs: Princeton Hall.

Ellingsæter, Anne Lise and Arnlaug Leira 2006. Introduction: Politicising Parenthood in Scandinavia. In Politicising Parenthood in Scandinavia, Anne Lise Ellingsæter and Arnlaug Leira (eds.), 1-26. Bristol: The Policy Press.

Esaiasson, Peter and Knut Heidar (eds.). 2000. Beyond Westminster and Congress: the Nordic experience. Columbus: Ohio State University Press. 
Esping-Andersen, Gøsta 1990. The Three Worlds of Welfare Capitalism. Cambridge: Polity Press.

Evangelical Lutheran Church in Finland 2012. Available from: www.evl.fi [Accessed 13 September 2013].

Fridolfsson, Charlotte, Ingemar Elander, Mikael Granberg and Erik Amnå 2009. FBOs and Social Exclusion in Sweden. In Faith-based Organisations and Social Exclusion in European Cities. National Context Reports, Danielle Dierckx, Jan Vranken and Wendy Kerstens (eds.), 161-195. Leuven: Uitgeverij Acco.

Foret, François and Xabier Itçaina (eds.) 2012. Politics of Religion in Western Europe: Modernities in Conflict? London: Routledge.

Green-Pedersen, Christoffer 2005. The Re-emergence of the Conflict of Conflicts in Western Europe: The Changing Nature of Party Competition in Western Europe. Aarhus: University of Aarhus.

Graneheim, Ulla H. and Berit Lundman 2004. Qualitative Content Analysis in Nursing Research: Concepts, Procedures and Measures to Achieve Trustworthiness. Nurse Education Today 24(2): 105-112.

Gustafsson, Göran 1985. Religiös förändring i Norden 1930-1980 (Religious Change in the Nordic countries 1930-1980). Malmö: Liber Förlag.

Hagevi, Magnus 2009. Politisk opinion och religiositet $i$ Västra Götaland (Political Opinion and Religiosity in Western Götaland). Lund: Sekel bokförlag.

Hagevi, Magnus 2010. Vad vill religionskritikerna? (What do the Religion Critics Want?). In Avstamp. Svenska folkets värden och syn på brännande samhällsfrågor, Surveyinstitutet vol 1, 119-146. Växjö: Linnaeus University Press.

Hagevi, Magnus (ed.) 2011. Den svenska väljaren (The Swedish Voter). Umeå: Boréa.

Hill, Michael 1973. A Sociology of Religion. London: Heineman.

Holberg, Sunniva E. 2007. Kampen om de kristne velgerne: mellom tro og tradisjon (The Battle for the Christian Voters: Between Faith and Tradition). In Norske velgere: en studie av stortingsvalget 2005, Bernt Aardal (ed.), 227-252. Oslo: Damm.

Høigård, Anne 1978. Språkbruken i partiprogrammer: en analyse av Høyres og Arbeiderpartiets arbeidsprogrammer for perioden 1973-77 (The language used in party platforms: an analysis of the Conservative Party and Labour work programs for the period 1973-1977). Oslo: Novus.

Ingebritsen, Christine. 2006. Scandinavia in World Politics. Lanham, Md: Rowman \& Littlefield.

Inglehart, Ronald and Christian Welzel 2010. Changing Mass Priorities: The Link Between Modernization and Democracy. Perspectives on Politics 8(2): 552-567.

Kestilä, Elina 2006. Is There Demand for Radical Right Populism in the Finnish Electorate? Scandinavian Political Studies 29(3): 169-191.

Knutsen, Oddbjørn 2010. The Religious Cleavage in 24 European Countries - A Comparative Study. Paper prepared for presentation at IPSA International Conference, Luxembourg, 18 20 March 2010.

Krippendorff, Klaus 1980. Content Analysis. An Introduction to its Methodology. London: Sage Publications Ltd.

Kühle, Lene 2011. Concluding Remarks on Religion and State in the Nordic Countries. Nordic Journal of Religion and Society 24(2): 205-213.

Laver, Michael and John Garry 2000. Estimating Policy Positions from Political Texts. American Journal of Political Science 44(3): 619-634. 
Lipset, Seymour Martin and Stein Rokkan (eds.) 1967. Party Systems and Voter Alignment: Cross-National Perspectives. New York, NY: Free Press.

Lundby, Knut 1985. Norge (Norway). In Religiös förändring i Norden 1930-1980, Göran Gustafsson (ed.), 154-195. Malmö: Liber Förlag.

Madeley, John 2000. Reading the Runes. The Religious Factor in Scandinavian Electoral Politics. In Religion and Mass Electoral Behaviour in Europe, David Broughton and Hans-Martien ten Napel (eds.), 28-43. London: Routledge.

Madeley, John 2003. A Framework for the Comparative Analysis of Church-State Relations in Europe. West European Politics 26(1): 23-50.

Manifesto Project 2013 [online]. Available from: manifesto-project.wzb.eu [Accessed $13 \mathrm{Au}-$ gust 2013].

Narud, Hanne Marthe and Henry Valen 2004. Partiprogram og velgerappell (Party Platform and Voter's Appeal). In I valgkampens hete. Strategisk kommunikasjon og politisk usikkerhet, Bernt Olav Aardal, Anne Krogstad and Hanne Marthe Narud (eds.), 33-58. Oslo: Universitetsforlaget.

Norden 2013. Population [online]. Available from: www.norden.org/en/the-nordic-region/population [Accessed 13 August 2013].

Norris, Pippa and Ronald Inglehart 2004. Sacred and Secular: Religion and Politics Worldwide. Cambridge: Cambridge University Press.

Pétursson, Pétur 1985. Island (Iceland). In Religiös förändring i Norden 1930-1980, Göran Gustafsson (ed.), 111-153. Malmö: Liber Förlag.

Przeworski, Adam and Henry Teune 1970. The Logic of Comparative Social Inquiry. New York: Wiley-Interscience.

Riis, Ole 1985. Danmark (Denmark). In Religiös förändring i Norden 1930-1980, Göran Gustafsson (ed.), 22-65. Malmö: Liber Förlag.

Skjeie, Hege 1992. Den politiske betydning av kjønn. En studie av norsk topp-politikk (The political significance of gender. A study of Norwegian state policy). Rapport 92:11. Oslo: Institutt for samfunnsforskning.

Sorensen, Kerstin 2011. Party Platforms and Public Childcare: Structural and Ideational Factors Shaping Policy in Norway and Sweden. Scandinavian Political Studies 34(1): 1-26.

Sundback, Susan 1985. Finland. In Religiös förändring i Norden 1930-1980, Göran Gustafsson (ed.), 66-110. Malmö: Liber Förlag.

Thorhallsson, Baldur and Christian Rebhan 2011. Iceland's Economic Crash and Integration Takeoff: An End to European Union Scepticism? Scandinavian Political Studies 34(1): 5373.

Tvedten, Hilde Marie 2010. Partiprogrammet som flerstemmig tekst. En retorisk genreanalyse av Arbeiderpartiets partiprogram 2009-2013 på bakgrunn av forslag som kom inn til programmet (The Party Platform as Polyphonic Text. A Rhetorical Genre Analysis of the Labour Party Platform 2009-2013 on the Basis of Proposals That Came Into the Platform). Unpublished Master thesis, University of Oslo. 